Journal of American Studies, 56 (2022), 4, 635-660

(C) The Author(s), 2022. Published by Cambridge University Press in association with the British Association for American Studies. This is an Open Access article, distributed under the terms of the Creative Commons Attribution licence (https://creativecommons.org/licenses/by/4.o/), which permits unrestricted re-use, distribution, and reproduction in any medium, provided the original work is properly cited.

doi:10.1017/S0021875821001298 First published online 10 January 2022

\title{
Sleepwalking, Class Mobility, and the Search for the Social Origins of Populism in Charles Brockden Brown's Edgar Huntly
}

\author{
WAYNE M. REED
}

This paper argues that Brown's sleepwalkers in Edgar Huntly offer us an early figuration for the problems inherent in the phenomenon we now refer to as "populism." Both populism and sleepwalking function through paradoxical and incongruent forms of expression that appear incoherent. The most prominent explanations that account for this paradoxical form of expression rely on an analysis of the breakdown of discourse. However, this paper argues that the incongruous form of expression is rooted in the reconfiguration of the social arrangements that enable Clithero and Edgar to advance socially but also places them in proximity to social crises. The contradictions of this position of social mobility are the source of the contradictions of the expression of sleepwalking. In depicting a world that makes social identity precarious, Brown offers us an explanation for how such paradoxical modes of expression are rooted in unstable resolutions of post-revolutionary society.

The general pretext dulls the perceptions of the half-revolutionary classes; it enables them to deceive themselves ... as to the consequences of its own deeds

\section{Karl Marx, The Class Struggles in France: I 848 to 1850}

He's a somnambulist - he walks in his sleep. I told you that they kicked him out of work, well, it started right after that.

$$
\text { Tatyana Tolstaya, "Sleepwalker in a Fog" }
$$

Can the sleepwalkers in Charles Brockden Brown's Edgar Huntly (1799) teach us anything about what we've come to call populism? Can reading Edgar Huntly help us get to the bottom of the causes, or the "springs of action," that animate populist expression and actuate their mobilization? Though virtually all scholars agree that Brown's sleepwalkers represent a 
test of a society's ability to be self-governed, few have correlated the nature of this threat to the specific form of populism despite striking similarities in how both are figured. ${ }^{\mathrm{I}}$ Populism is a distinct form of political expression that arises when popular indignation flares up without a developed political organization to channel its energies. ${ }^{2}$ As a result, populism is marked by the perplexing tendency to deal in contradictions and paradoxical discourses which tend to take on a life and a logic of their own, only barely corresponding to the waking life of ordinary politics. ${ }^{3}$ Like the sleepwalker who navigates the external world with eyes half-open, aware enough of obstacles to avoid injury, the populist is savvy enough to sense the corruption of the elite, but their antagonism is uniquely prone to wild accusations, conspiracy theories, and imaginative constructions that, to the outside observer, are barely conceivable but, to the populist, are so deeply invested with extreme affect that the populist becomes, like the sleepwalker, insensible to the boundaries that govern everyday norms of

I The idea that Brown's sleepwalkers expose the limits of postrevolutionary society dates back to at least Leslie A. Fiedler's Love and Death in the American Novel, revised edn (New York: Stein and Day, 1966). Some of the most notable in this line of thinking include Jared Gardner, "Alien Nation: Edgar Huntly's Savage Awakening," American Literature, 66, 3 (1996), 429-6I, an article that sees in Brown's sleepwalkers the expression of a fear that foreign influences will rupture the foundations of the new republic; Edward Cahill, "An Adventurous and Lawless Fancy: Charles Brockden Brown's Aesthetic State," Early American Literature, 36, I (200I), 31-70, which lays out the way republican thinkers envisioned the role aesthetics played in guaranteeing the stability or contributing to the instability of republican institutions; Justine Murison, "The Tyranny of Sleep: Somnambulism, Moral Citizenship, and Charles Brockden Brown's Edgar Huntly," Early American Literature, 44, 2 (2009), 243-70, which argues that Brown's sleepwalkers critique the republican contradiction that a citizen is expected to be molded by institutions but also must exert self-control; and Paul Downes, "Sleep-Walking out of the Revolution: Brown's Edgar Huntly," Eighteenth Century Studies, 29, 4 (1996), 41 3-3 I, which figures sleepwalking as a kind of destructive mode of indecision caused by the ideological contradictions of postrevolutionary society.

${ }^{2}$ Historians of early America tend to see this lack of party organization and infrastructure as a key feature of popular movements and rebellions. See Stanley Elkins and Eric McKitrick, The Age of Federalism: The Early American Republic, 1788-I800 (New York: Oxford University Press, 1993); Terry Bouten, Taming Democracy: "The People," the Founders, and the Troubled Ending of the American Revolution (New York: Oxford University Press, 2007).

3 Though Richard Hofstadter's characterization of popular movements as incorrigibly irrational, paranoid, and conspiratorial has fallen somewhat out of fashion in academic circles, scholars of populism still characterize populist rhetoric as virtually unintelligible on its face. Jan Werner-Müller's characterization of populist expression as willfully paradoxical dominates the pluralist school of populist studies. Jan Werner-Müller, What Is Populism? (Philadelphia: University of Pennsylvania Press, 2016). Ernesto Laclau's more theoretically rigorous framework understands populist expression as a floating signifiers, which cannot be understood by the content of the expression itself but by its nature as a form of antagonism. Ernesto Laclau, On Populist Reason (London: Verso, 2005). 
behavior. ${ }^{4}$ The urgency and indignation invested in these antagonistic figments seem to overtake the faculties of discernment requisite for deliberative political negotiation, opening a pathway for irrational and sometimes violent behavior, creating the conditions in which the subject becomes unaware of the consequences of their actions. In essence, what characterizes both sleepwalking and populism is that their affective investment is channeled into internal logics that do not correspond to the normal functions of social and political life.

Brown's fiction, like studies of populism, is devoted to seeking out the causes of such irrational and seemingly inscrutable behavior. ${ }^{5}$ However, because the expression of sleepwalking in itself is so paradoxical, Brown scholars have rarely sought out the answer in the material social relations, choosing instead to account for them in some other way. ${ }^{6}$ The same is the case for studies of populism. Like some scholars of populism, many Brown scholars have sought the answer in universal and ahistorical categories such as innate depravity, the human tendency toward irrational or "savage" behavior, or the Freudian unconscious, leaving readers with a fatalistic sense that no

${ }^{4}$ Hofstadter argues that "what distinguishes the paranoid style is not, then, the absence of verifiable facts ... but rather the curious leap in imagination that is always made at some critical point." Richard Hofstadter, The Paranoid Style in American Politics (New York: Vintage, 2008), 37. The conspiratorial mode is one of the clearest examples of how populist antagonism creates unverifiable popular narratives. For the debate on the conspiratorial mode in early America see also Gordon Wood, "Conspiracy and the Paranoid Style: Causality and Deceit in the Eighteenth Century," William and Mary Quarterly, 39, 2 (1982), 40I-4I; and Ed White, "The Value of Conspiracy Theory," American Literary History, I 4, I (2002), I-3 I. Of these, White is the only one who analyzes the way in which conspiratorial rhetoric is a function of social relations.

5 In Brown's essay "The Difference between History and Romance," Monthly Magazine and the American Review, 2, 4 ( 1800 ), 25 I-53, he states very straightforwardly that the role of fiction, or "romance," is to speculate on the causes and motives of actions when they are not directly observable. See The Charles Brockden Brown Electronic Archive and Scholarly Editions, http://brockdenbrown.cah.ucf.edu/ $\mathrm{xtf}_{3} / \mathrm{view}$ ?docId= $=1800-0425 \mathrm{I} \cdot \mathrm{xml}$; query= history\%2oand\%2oromance; brand=default (accessed I 4 April 202 I).

${ }^{6}$ Much of the scholarship on Brown has rendered sleepwalking in Edgar Huntly anomalous, detached, and unaccountable, characterizing it as "mental disorder" or "delirium": Michael Davitt Bell, The Development of American Romance: The Sacrifice of Relation (Chicago: The University of Chicago Press, I 980), 54; "incoherence": Beverly R. Voloshin, "Edgar Huntly and the Coherence of the Self," Early American Literature, 23, 3 (1988), 262-80, 263; or "a chaos of images": Edward Cahill, "An Adventurous and Lawless Fancy: Charles Brockden Brown's Aesthetic State," Early American Literature, 36, I (200 I), 3 I-70, 54. In this strain of thinking, sleepwalking is as an epistemological darkness rather than a way of being in the world. Of all the readings that limit sleepwalking to these blackout states, the most thoughtful, complex, and productive is Justine Murison, "The Tyranny of Sleep: Somnambulism, Moral Citizenship, and Charles Brockden Brown's Edgar Huntly," Early American Literature, 44, 2 (2009), 243-70. For a discussion of the ways in which sleepwalking in Brown's fiction has been so adaptable to psychoanalytic treatments see Emily Ogden, "Edgar Huntly and the Regulation of the Senses," American Literature, 85, 3 (2013), 4I9-45. 
political or social structure will ever keep these forces at bay. ${ }^{7}$ Others, following a post-structural line of reason, take both sleepwalking and populism as irreducible to the problem of signification. ${ }^{8}$ Both trends attempt to account for the floating nature of sleepwalking and populist expression, the irrational adherence to chimeras or its investment in empty signifiers, by minimizing the historical social contexts that precede the sleepwalking episodes in Edgar Huntly and populist expression in the public sphere. However, we can only consider Edgar and Clithero as universal representatives of ahistorical human tendencies toward depravity if we continue ignoring the egregiously overlooked fact that they both represent a historically distinct social position: a newly empowered popular class of the socially mobile. And though Brown is uniquely attentive to the contradictions in the production of meaning, we don't do justice to Brown's fictional method if we ignore the way that the contradictions of this social position precede and shape the contradictions of meaning and expression in the novel. In short, Brown's novel enables readers to see how the shape of an inscrutable expression originates in the contradiction of a material social relation.

In his fiction, Brown sought to contribute to the empirical inquiry about how the internal self integrates into the order of the external world by investigating the causes of those instances in which excessive affect causes the mind to become insensible to the outside world. Sleepwalking, however, is a particular kind of insensibility. ${ }^{9}$ Unlike the colonialist conceptions of "savagery" that

7 Modern accounts of populism that rely on assumptions about universal human tendencies towards depravity date back to at least Gustave Le Bon, The Crowd: A Study of the Popular Mind (New York: Dover, 2002); and Sigmund Freud, Mass Psychology and the Analysis of the "I" (New York: Penguin, 2004), I 5-IOI. They still persist today in works like John Lukacs, Democracy and Populism: Fear and Hatred (New Haven, CT: Yale University Press). The prominence of Freudian psychoanalysis in studies of Brown's work began with Leslie Fiedler's Love and Death in the American Novel and petered out in the I 990 s. Yet even works like Jared Gardner, "Alien Nation: Edgar Huntly's Savage Awakening," American Literature, 66, 3 (1996), 429-6 I; and Christopher Stampone, "A Spirit of Mistaken Benevolence': Civilizing the Savage in Charles Brockden Brown's Edgar Huntly," Early American Literature, 50, 2 (2015) 41 5-48, still argue that Brown bought into ahistorical notions of human depravity or "savagery" as the the source of the violent behavior that impinges on the progress of civilization.

8 The post-structural articulation of "the people" as unrepresentable dates back to Claude Lefort, Democracy and Political Theory (Cambridge: Polity Press, 1988), but finds its most clear and influential articulation in Laclau's On Populist Reason, in which he accounts for populism as a problem of empty signifiers. For its articulation in the early American period see Jason Frank, Constituent Moments: Enacting the People in Postrevolutionary America (Durham, NC: Duke University Press, 2010). Paul Downes's treatment of Edgar Huntly in "Sleepwalking out of the Revolution" frames sleepwalking within this same post-structural framework.

9 Beverly Voloshin, 262-80, argues that Charles Brockden Brown uses his sleepwalking characters to undermine John Locke's assumption that the mind and nature cohere. Edward 
attribute insensibility to the subject's flouting of the pleasure principle to wildly pursue desire and vengeance without restraint, Brown's sleepwalkers channel their extreme affect into a pretext, a restrictive logical formulation, or regime of signification, that has some basis in the order and logic of the external world. The pretext is like a rumor or hint with only a piece of the story attached to it, yet it becomes so compelling that it is taken to be true, and the more one believes and invests in it, the more removed from reality their state of mind becomes. Rather than allowing internal desire to overwhelm all sense of the external world, the pretext becomes the container of affect, programing the body's actions and coding its meaning. Yet neither can Edgar or Clithero be directly compared to enthusiasts like Theodor Wieland or Martinette de Beauvais, who align their actions to deeply held internal convictions about the righteousness of a principle at the expense of "everything mortal and perishable." ${ }^{\circ}$ Like the enthusiast, the sleepwalker channels affect into the logic of an unverifiable pretext, but they are neither wholly disinterested nor wholly willful. Turned one way, the sleepwalker uses the pretext to fulfill a desire; turned the other, the sleepwalker is dominated by the logic of the pretext which guides them half-unknowingly down a path of potential self-destruction. Sleepwalking, then, is marked by the intense power of the affective rationale, or pretext, to dominate the subject's actions.

If the sleepwalker's internal understanding is irreconcilable to the outer world, it is not a function of repression of wild desire, nor is it a function of enthusiastic devotion; rather it is a function of a social position. We might say that sleepwalking is a response to what Ed White calls a feeling of structure. That is, Clithero and Edgar internalize their precarious social positions,

Cahill uses David Hume to highlight the aesthetic dimensions of Brown's approach to the question of the integration of the self with nature. And Chad Luck, "Re-walking the Purchase: Edgar Huntly, David Hume, and the Origins of Ownership," Early American Literature, 44, 2 (2009), 27I-306, likewise uses David Hume to emphasize the way settler colonial relations play a role in integrating the self with nature. For an account of early American understanding of insensibility, see Ogden.

10 David Hume, "Of Superstition and Enthusiasm," in Hume, Selected Essays, ed. Stephen Copley and Andrew Edgar (New York: Oxford, 2008), 38-42, 39. John Locke, An Essay Concerning Human Understanding (New York: Penguin, 2004), 6 I 6, establishes enthusiasm in the empirical tradition as that frame of mind which replaces reason with "the ungrounded fancies of man's own brain and assumes them for a foundation both of opinion and conduct." What distinguishes the enthusiast, however, is that they consider themselves to be in "frequent communication with the divine spirit." David Hume agrees with the characterization of enthusiasm, yet he sees it as a friend to the process of civil liberty. For the revolutionary implications of enthusiasm and an account of Martinette as an enthusiast see John MacKilgore, Mania for Freedom: American Literatures of Enthusiasm from the Revolution to the Civil War (Chapel Hill: University of North Carolina Press, 2016). 
which manifest in "a structural need to move." "I Both rise to social positions above the stations they were born into, yet their upward mobility is conditioned on the removal of previous occupants of power, the patriarchal aristocracy and the Lenne Lenape respectively. This ensures that their access to wealth and stability are provisional and unstable because the societies that invite them in have failed to resolve the contradictions that enabled their social advancement in the first place. Within these social modes, however, Clithero and Edgar both lack the habits and loyalties that come from being firmly rooted in those class societies. As upwardly mobile subjects, they feel the internal contradictions of the societies that have invited them in. The sleepwalking state of mind thus emerges at the intersection of both the internal contradictions of their positions within these new modes of social reproduction and the contradictions of their relationship to the displaced. Because neither is habituated enough in their respective societies, those social logics are incapable of containing or channeling the extreme affect that these insecure positions produce.

Sleepwalking, then, is an uncontrollable expression of social insecurity, a function of social crisis among the socially mobile class. In moments of crisis, the socially mobile cannot assert themselves from a stable position of power as the wealthy merchant, banker, or aristocrat can. Nor do they have recourse to assert a strong sense of lower-class identity as, say, European peasants might have. Moments of crisis scramble the sleepwalker's social identity, allowing them to latch onto an order of logic that does not correspond to the logic that governs the mode of social reproduction in which they operate. In this way, Brown's sleepwalkers are just like populists: they are the precariously empowered, keenly aware that they are one crisis away from ruin. Populist expression thus emerges "out of the failure of existing social and political institutions to confine and regulate subjects into a relatively stable social order." ${ }^{22}$ In these moments of crisis, "social turmoil and social mobility alter established identities, loosen traditional relations of subordination and open up new forms of identification." " 3 In these moments of crisis, the expression of those in precarious social positions becomes unpredictable and vulnerable to the seductive logic of concepts that do not correspond to any empirical social logic but only to imagined connections.

${ }_{11}$ "The cultural response to this dispersal-in-war is flight, which means not so much simple physical movement ... but the feeling of a structural need to move." Ed White, The Backcountry and the City: Colonization and Conflict in Early America (Minneapolis: University of Minnesota Press), 52. Sleepwalking is an expression of the internalization of movement, a type of flight, that responds directly to threats of violence that stem from the social position that Clithero and Edgar occupy.

12 Francisco Panizza, "Introduction: Populism and the Mirror of Democracy," in Panizza, ed., Populism and the Mirror of Democracy (London: Verso, 2005), I-32, 9. 
In what follows, I offer an updated reading of Edgar Huntly that explains why Clithero attacks the Lorimers under the pretext of a mystical aristocratic logic and why Edgar's identity blurs with the Lenne Lenape warriors. Rather than understanding Edgar's sleepwalking as an imitation of Clithero's, I argue that the determining conditions for Edgar's sleepwalking precede his interactions with Clithero. In fact, even though each occupies a distinct geographic mode of social reproduction and adopts a distinct pretext, the form that sleepwalking takes and the sociohistorical process that conditions that form are identical in both instances. In this way, Brown's novel enables us to see how a reactionary expression can crop up in different social and geographical modes yet arise from the same material process and share the same form. It is here that Brown can contribute to our analytic understanding of populism by answering the question of how to account for the consistent form of populist expression across borders without minimizing the material differences that ground them. For Brown, neither ideological convictions nor the material interests in which those convictions are grounded animate the reactionary expression. Rather, those expressions are animated by modern society's inability to ground identity in secure modes of reproduction for the newly empowered and its inability to resolve the consequences of its displacement.

The conflict that animates Clithero's story and the conditions that produce his sleepwalking state consist entirely of materials that precede him. The struggle that intersects with class and gender originates in the character of Euphemia Lorimer, Clithero's benefactress, who as a young woman in an English aristocratic family has been denied a marriage to her preferred lover, Sarsefield. Her brother, Wiatte, vehemently opposed to the match on the grounds that Sarsefield is of a lower class, succeeds in banishing Sarsefield and marrying his sister off to an aristocrat named Lorimer, not just to preserve class distinction in the family but presumably also to keep the family solvent, as Wiatte is a typical profligate aristocrat, whose bad habits leave him perennially indebted. When these bad habits go too far, he is arrested and, with the consent of his sister, sent away on a prison ship to one of the penal colonies of colonial America, where he is presumed killed during an attempted mutiny. Having experienced the gender repression of aristocratic life, Mrs. Lorimer, widowed and in full control of her estate, organizes her microsociety according to more enlightened principles, allowing the sentiment that was denied her to influence her decisions. Bucking custom, she adopts her brother's illegitimate child Clarice and treats her as a legitimate member of the family. On one of her estates in Ireland, she recognizes talent in the young peasant Clithero, takes him in and rewards his loyalty and his merit by putting him in charge of the management of her estate. When Clithero and Clarice fall in love, rather than spurn the match 
between an upwardly mobile peasant and an illegitimate niece, Mrs. Lorimer endorses the match, positioning Clithero and Clarice as heirs to Mrs. Lorimer's wealth. Clithero's story, then, is a story of class mobility made possible by Mrs. Lorimer's new order of enlightened sentimentality.

But this progressive mode of social reproduction that Mrs. Lorimer attempts to create in her household functions because of a delicate balance she strikes between the contradictory forces that have enabled her position. Indeed, Mrs. Lorimer acts the part of the enlightened progressive in providing Clithero a merit-based path to social mobility, but Clithero's position is nevertheless one bestowed by the generous and atypical actions of a patroness. Because Clithero's upward mobility is both merit-based and patronage, he occupies a dependent position that nonetheless carries with it the illusion of independence. This contradiction rises to the surface when Clithero assumes that his affection for Clarice is an offense to Mrs. Lorimer. Clithero, who is prepared to leave the household in order not to offend her aristocratic sensibilities, is surprised when Mrs. Lorimer embraces the match and endorses his affections as "rational and just." ${ }_{44}$ She even chastises Clithero for thinking that she would do otherwise, saying, "I know your scruples, Clithero, and am sorry to see that you harbour them for a moment. Nothing is more unworthy of your good sense." Is Though she offers her consent with alacrity, Clithero's feeling of impertinence registers the fact that, in her position, Mrs. Lorimer has the right to act either according to exclusive aristocratic family mores or according to enlightened sentiment. In consenting to the match, she legitimizes Clithero's and Clarice's natural affections, presumably solidifying her commitment to a new mode of social reproduction unbound by the borders of class and bloodlines. But she does so from a position of personal authority. Even as she embodies rational principles that are seemingly designed to facilitate the independence of his rational sentiments and merit, her power is not reinforced by any social institution, only by her personal integrity and commitment to enlightenment principles.

While Mrs. Lorimer is able to reconcile Clithero's peasant origins to his present class position, he cannot. Though he adapts to the practices, behaviors, and manners of the enlightened aristocratic mode of social reproduction, he has not integrated his beliefs to this practice of everyday life. The idea that beliefs derive from habits and customs of everyday life was widely accepted in the empirical tradition to which Brown's novels contribute. ${ }^{16}$ For David

${ }^{14}$ Charles Brockden Brown, Edgar Huntly, or Memoirs of a Sleepwalker, ed. Philip Barnard and Stephen Shapiro (Indianapolis: Hackett Publishing, 2006), 39.

is Ibid.

${ }^{16}$ For Hume's influence on Brown see Paul Gilmore, "Charles Brockden Brown's Romance and the Limits of Science and History," ELH, 84, I (Spring 2017), I 17-42; James Dawes, 
Hume, for example, repeated experiences enable a person to expect and "draw inferences" about the most likely outcomes, and the reliability of these accumulated experiences forms a complex network of belief, which occupies a place of authority in the mind. In all the regular practices of everyday life, people "take their measures from past experience ... and firmly believe that men, as well as the elements, are to continue, in their operations, the same, that they have ever found them." ${ }^{17}$ By governing expectations, belief governs behavior, allowing people to function and integrate into the external world. If Clithero's "good sense" is not yet compatible with Mrs. Lorimer's own commitment to rational justice, it is because his experience within the mode of social reproduction that Mrs. Lorimer represents is not rooted enough to shed the habit of mind that he formed as a peasant.

Clithero lacks a firm belief in Mrs. Lorimer's progressive new order because he still senses that he occupies a position that is made unstable by the residual presence of the old mode of dependence. Though Mrs. Lorimer's commitment to enlightened sentiment has resolved the internal conflict within her class that kept sentiment from prevailing in a rigid system of aristocratic convention, Clithero's reluctance to reveal his feelings for Clarice shows that her new position has not totally resolved the external contradiction between classes, a contradiction that defines Clithero's position. Clithero's internalization of Mrs. Lorimer's position of authority prompts him to assume, without asking, that Mrs. Lorimer will revert to aristocratic tendencies, and he is prepared to take self-denying measures that allow Mrs. Lorimer to continue in an aristocratic mode. And though Mrs. Lorimer is intent on leaving the past behind, the past is still present in Clithero's position in the household.

In a sense, Mrs. Lorimer has created a popular subject by advancing Clithero's social station, but in doing so, she has created the conditions of populist reaction. Just as the modern revolutionary states of the late eighteenth century subjected their authority to popular sovereignty and yet vested themselves with real power, Mrs. Lorimer legitimizes her real power by authorizing Clithero's talents and feelings. In both cases, those in power rest their legitimacy not just on securing political approval of their authority but on securing the position of the people in the new social arrangement. Because common people are placed in a newly empowered position in this new sociopolitical arrangement, they have new grounds from which to react when they feel displaced. Indeed, it is Clithero's sense of imminent displacement that generates

"Fictional Feeling: Philosophy, Science, and the American Gothic," American Literature, 76, 3 (Sept. 2004), 437-66; Luck.

${ }^{17}$ David Hume, An Enquiry Concerning Human Understanding, ed. Peter Millican (New York: Oxford University Press, 2008), 65. 
his reaction. Despite all assurances that she has provided a just and stable society, Mrs. Lorimer's authority cannot overcome Clithero's suspicion that he is subject to her whims and that his displacement is imminent. Because Clithero's feelings are not fully integrated into the new mode of social reproduction, Mrs. Lorimer cannot achieve the full closure of an enlightened society, and though Clithero is formally included in her society, his sense of internal displacement is the condition of his reaction. ${ }^{18}$

If unity of form in Brown's work matters at all, we should be mindful that this dynamic between Mrs. Lorimer and Clithero provides a consistent frame for the next crisis. When her brother Wiatte mysteriously returns, challenging Mrs. Lorimer's ability to continue reproducing a progressive and enlightened household, Clithero's response originates in exactly the same conflict that informs his response to his love for Clarice. Just as Clithero assumed that his love for Clarice would reanimate an aristocratic sensibility in Mrs. Lorimer at the cost of his social position, Wiatte's return suggests "dreary forebodings" of a return of old aristocratic social mores that threaten to put Clithero's position in the household in jeopardy again. As "the future was no longer a scene of security and pleasure," Clithero again feels no assurance that Mrs. Lorimer will maintain her enlightened customs or that his class mobility will prevail. ${ }^{19}$ Though Wiatte's return is the occasion of Clithero's crisis, it only further exposes the already existing contradiction in the class relation between Mrs. Lorimer and Clithero that was made apparent in her endorsement of his match with Clarice. The only way to continue in his upwardly mobile position is to rely on Mrs. Lorimer's ability to ward off her brother's influence. That is, when a crisis hits, when Clithero's social position is put in jeopardy, he depends for his mobility on her personal commitment to progressive enlightenment.

The sensation of class precarity is the beginning of the emergence of Clithero's sleepwalking. The external social world, that is, produces an internal phenomenon in Clithero's mind. Wiatte's abrupt reappearance and all the implications that surround the moment induce a panic, an intense affective state that on a physiological-affective level turns his body inside out. It keeps him awake when he should be sleeping and compels his body to be in motion when he should be still: "To sleep, while these images were haunting me, was impossible. I passed the night in continual motion. I strode, without ceasing, across the floor of my apartment. My mind was wrought in higher

${ }^{18}$ For an illuminating account of populism as a reaction to internal displacement see Benjamin Arditi, "Populism as an Internal Periphery of Democratic Politics," in Arditi, Politics on the Edges of Liberalism (Edinburgh: Edinburgh University Press, 2007), 54-87.

19 Brown, Edgar Huntly, 48. 
pitch than I had ever before experienced." ${ }^{\circ}$ In this state of helplessness, when his actions cannot prevent Wiatte's return or compete with his influence over Mrs. Lorimer, he is immobilized. The sensation of social immobility sets his body in motion.

This state of reverie in which Clithero's body moves at the behest of an excited mind and his dreams are beyond his control, though not yet a technical case of sleepwalking, is still a form of sleepwalking as Brown would have understood it. Erasmus Darwin, a key influence on Brown's writing, does not consider sleepwalking an isolated phenomenon but one that appears on a spectrum of semi-detached states of mind. As he points out, "Sleepwalking is a part of reverie," a state which he defines as "distinguished from madness and from delirium because the train of ideas are kept consistent by the power of volition, as the person reasons and deliberates in it." ${ }_{21}$ That reverie and sleepwalking are, here, continuous and barely distinguishable shows us that sleepwalking is continuous with other forms of insensibility, which Emily Ogden lucidly defines as a state in which the mind shuts itself off from external stimuli, leaving a person "wrapped up in imaginatively embellished sensations to the exclusion of real input." 22 If we only understand sleepwalking to consist of those moments of blackout in which the memory is disengaged, we miss the way in which these states of reverie connect the pieces of the whole story. That is, if sleepwalking is limited to those nocturnal states of unconsciousness then we read those episodes as disruptions rather than continuation, and we see Brown's sleepwalking stories as more fragmented than they really are. Instead, we should see each of the sleepwalking stories as starting off with a crisis that puts them in a "sleepwalking" state of mind that includes these excited reveries as preludes. Clithero is a sleepwalker in his story even though we don't see his fully unconscious meanderings until he arrives in Pennsylvania. Sleepwalking is a function of the crisis state of mind.

The fact that the sleepwalking state of mind is, as Darwin puts it, "kept consistent by the power of volition" even as it shuts itself off to the external world, suggests that the sleepwalking state of mind is a figure for the type of radical form of abstract reasoning that transatlantic conservatives in Brown's day cast as spectral and demagogic. Brown likewise makes the argument that the internal consistency of these "systems" gives them a kind of seductive power that invites an intensely affective investment by its adherents. This affective investment comes at the expense of the evidence that experience of the external world provides but nevertheless invests these systems "with a seeming

\footnotetext{
${ }^{20}$ Ibid.

${ }^{21}$ Erasmus Darwin. "Of Volition," in Brown, Edgar Huntly, 20 I-5, 203.

22 Ibid. 426.
} 
existence." ${ }_{23}$ Abstract reasoning produces "fleeting, misty, and dubious" notions but is taken "for a sensible present existence." ${ }^{24}$ Like the popular actions of revolutionary movements, sleepwalking also carries this affective investment in internally consistent ideas. For Darwin, "the ideas of the mind are obedient to the will, because the patient's discourse is consistent though he answers imaginary questions." 25 In other words, there is a distance between the abstract reasoning and the sensible world that blurs the intentions of the will.

Clithero is already in a sleepwalking state of mind when he unexpectedly encounters and kills Wiatte in self-defense. The threat to his advancement has already made him susceptible to investing heavy amounts of affect into enclosed narratives. The fact that he experiences this encounter with Wiatte as an involuntary act in which he is "impelled by an unconscious necessity" becomes the material that his imagination uses to create the enclosed train of thoughts that dictate his actions. ${ }^{26}$ Whether or not self-defense justifies the act, he does not experience it as a rational act; rather, "the attack was so abrupt that my thoughts could not be suddenly recalled from the confusion into which they were thrown. My exertions were mechanical." ${ }^{27}$ The question of how voluntarily or involuntarily he acted becomes a crucial paradox. Clithero is under the influence of instinct and self-preservation when he kills Wiatte, but Wiatte still dies by Clithero's hand. He acts autonomously in defending himself, but inasmuch as he acts according to instinct, he is automated. Clithero is thus reflecting on an experience that is itself a kind of sleepwalking.

Clithero's inability to make sense of this paradox of intention will become the empty ground on which he adopts the train of associations, or pretext, that convince him that he must kill Mrs. Lorimer. This is the precise moment in which Clithero transforms from someone whose actions and behaviors conform to the mode of social reproduction that reinforce his class mobility to someone whose actions are incongruous with that mode. Althorpe marks this same groundlessness as the moment of transformation in Brown's story "Somnambulism: A Fragment" when he says,

${ }^{23}$ Charles Brockden Brown, "Walstein's School of History: From the German of Krants of Gotha [second and last part]," Monthly Magazine, I, 6 (Sept.-Dec. 1799), 407-I I, 408, The Charles Brockden Brown Electronic Archive and Scholarly Editions, http://brockdenbrown.cah.ucf.edu/xtf $3 /$ view?docId=1799-I 2407.xml (accessed 25 May 2020).

24 Ibid., 408.

${ }^{25}$ Darwin, 202-3. On the conflict between abstract theoretical conceptions and traditional authority in this time period see David Simpson, Romanticism, Nationalism and the Revolt against Theory (Chicago: The University of Chicago Press, 1993).

${ }^{26}$ Brown, Edgar Huntly, 52.

${ }^{27}$ Ibid. 50-51. 
The strength of a belief, when it is destitute of any rational foundation, seems, of itself, to furnish a new ground for credulity. We first admit a powerful persuasion, and then, from reflecting on the insufficiency of the ground on which it is built, instead of being prompted to dismiss it, we become more forcibly attached to it. ${ }^{28}$

Indeed, the groundlessness of the claim is the source of Clithero's affective investment in it: "My lady, said I, believed her fate to be blended with that of Wiatte. Who shall affirm that the persuasion is a groundless one?"29 In other words, Clithero is not rationally convinced of the claim that fate dictated his killing of Wiatte or that it dictates that he murder Mrs. Lorimer, but he is affectively convinced. In this moment of crisis, the imagination exercises greater authority over his mind than experience. It is in the contemplation of this train of associations that Clithero's "senses had been hushed [as if] in sleep, while the powers of locomotion were unconsciously exerted to bear me to my chamber." 30 The internal logic of his account of the murder becomes more consistent as the influence of his external environment fades. As the void opens before him, an internal belief in a purely metaphysical narrative solidifies: he is a tool of fate.

Clithero has no rational ground to believe so intensely that Mrs. Lorimer's fate is tied to her brother's. For Paul Downes, the collision between Clithero's reverence for Mrs. Lorimer and a deep sense of guilt "encourage[s] Clithero to give credence to Mrs. Lorimer's prophetic fancy."3 I However, Downes presents these as two unconflicted affects, whose meanings are ultimately only relevant inasmuch as they contribute to an allegory of revolution. Yet, as we noted earlier, Clithero's "reverence" for or deference to Mrs. Lorimer is undergirded by conflicted feelings about his dependence on her. As for his guilt, Clithero certainly sees his act of bodily and social self-defense as a "contemptible and dastardly regard to my own safety" in which he failed to live up to his devotion to Mrs. Lorimer, but he is also hyperaware that killing Wiatte "bore the appearance of a desirable event" by eliminating the threat to his social position. ${ }^{32}$ In other words, Clithero's gratitude to Mrs. Lorimer is mixed with resentment about his social position, and his guilt over the death of Wiatte is mixed with relief at the death of an urgent threat to his social position. Clithero's contradictory feelings furnish the irrational ground on which he comes to believe, as he does when his affections for Clarice reveal themselves, that he lives in a world made for aristocrats. This is not a clash between two coherent ideologies for and against revolution; rather it is an incoherent expression of a feeling of displacement from a newly empowered popular subject.

\footnotetext{
${ }^{28}$ Charles Brockden Brown, "Somnambulism: A Fragment," in Brown, Edgar Huntly, 24458, 248.

${ }^{31}$ Downes, "Sleepwalking out of the Revolution," 4 I 9. 
This mythic narrative of fate, internally consistent and existing only in his imagination, is the product of a recoil against the materiality of his act. Clithero denies the senses of the bystanders who proclaim that his act was justified by self-defense. He denies Mrs. Lorimer's past actions in support of rationally derived conclusions, and in turn denies her the opportunity to act sensibly. And by believing that he is only a pawn in their game, he ultimately denies any hint of self-interest in his act. Of course, Clithero doesn't pull this aristocratic mythos out of thin air; it still lingers in Mrs. Lorimer, who, for all her progressive actions, still holds onto a belief that she and her brother were "linked together by a sympathy whose influence was independent of sensible communication." ${ }_{3} 3$ Yet, in Clithero's state of mind, it becomes the pretext that allows him to deny the material self-interest of his act and compel him to violence.

Were Clithero to nurture a resentment against Mrs. Lorimer for turning him out, or were he to express gratitude for her overcoming her feelings and relying on a sense of justice, either response would be compatible with a normalized regime of feelings. But this response could only come after Mrs. Lorimer had responded to the act. Clithero doesn't wait for her to respond. Instead, in his sleepwalking state, he acts out both gratitude and resentment. As he becomes more resigned to the notion that he will lose his position in her household, he becomes, in his mind, more devoted to Mrs. Lorimer. His language about her character becomes more lofty. The gratitude that is commensurate with the enlightened mode of social reproduction morphs into an obsequious and reverent admiration that is more indicative of the residual aristocratic mode of social reproduction. And yet, even as this logic of devotion organizes his thoughts, his body moves in an attempt to murder her. In conforming his mind to the old aristocratic mythos, the same ideology that animated Wiatte, Clithero enacts a twisted mix of devotion and resentment against Mrs. Lorimer under the pretext of the aristocratic mythos.

Clithero feels the reality of the contradiction of his living relation to Mrs. Lorimer even before Wiatte returns. But the abrupt and violent encounter with Wiatte puts extreme pressure on that contradiction. Clithero's attack on Wiatte is both a liberation and a source of crisis because while it removes the most obvious threat to his social mobility, it also potentially awakens Mrs. Lorimer's aristocratic sensibility and definitely reawakens an internalized sense of his social dependence and inferiority. Before he lets the crisis immobilize him, Clithero mobilizes himself and becomes the embodiment of Mrs. Lorimer's nemesis, revisiting on her the old masculine and

33 Ibid., 54. 
class-bound aristocratic ideology that she had tried to put in the past by promoting Clithero's advancement.

Because this response is incompatible with any coherent regime of feelings or reason, we cannot qualify sleepwalking as a form of deliberative resistance. It is, rather, a form of reaction. Yet neither is it merely an individualized psychological phenomenon. Clithero's reaction is shaped directly from the conditions of his social situation. His expression of gratitude and devotion arises out of Mrs. Lorimer's authorization of his talents and feelings, and his resentment arises out of his subjection to her arbitrary authority, but in the moment of crisis these logics twist into a sleepwalking state of mind in which his thoughts and actions fail to logically cohere with the external order of the world. Because it emerges from a newly empowered subject experiencing a crisis of mobility, sleepwalking is a figure for a distinct kind of popular reaction that originates in this historically novel form of social relationship that is made all the more volatile for its tendency towards crisis. In other words, the incoherence of Clithero's reaction is a manifestation of a form of social empowerment that situates people in close proximity to crisis. It is this form that distinguishes the populist reaction from other forms of coherent resistance.

Clithero's story shows us that we can make sense of - or at least identify the contradictions inherent in - his bizarre reaction if we focus on how social tension bears down on the class-mobile subject and determines the internal conflict. This observation depends, however, on realizing that the single act of sleepwalking alone does not make a character a sleepwalker. The sleepwalking state of mind really begins at the onset of the crisis that jeopardizes their social advancement, which induces a panic that sets in motion the process of shutting down the connection between the internal mental process and external influence. Most scholars have missed the fact that Edgar inhabits the form of the sleepwalker even before he meets Clithero. Because Clithero's story occupies so much space in a novel primarily about Edgar, scholars have tended to assume that Clithero's appearance in Edgar's life is the central disrupter and the organizing catalyst of Edgar's sleepwalking. They suggest that Edgar becomes a sleepwalker because of Clithero's influence, an assumption that allows authors to interpret Edgar as a gullible reader who naively falls under the spell of Clithero's novelistic rendering of his past. ${ }^{34}$ It also allows

${ }^{34}$ Michael Bell, The Development of American Romance, 54, argues that "Edgar unconsciously begins to imitate" Clithero's behavior and is thus "transformed into a somnambulist." Many of the subsequent versions of this position seem to be inspired by an interest in the implications for republican society of the regulation of aesthetic responses. See Edward Cahill's "An Adventurous and Lawless Fancy"; and Emily Ogden, "Edgar Huntly and the Regulation of the Senses," 419-45. 
scholars to allegorize Edgar as a stand-in for the fate of the young nation, vulnerable to the sinister influences of foreigners infiltrating national borders, readings that risk turning Edgar, and the young United States that he represents, into something of blank slate, a naive and ingenuous innocent whom outside influences can corrupt. ${ }^{35}$ In a way, they give cover to Edgar, attributing the violence that he enacts against the Lenne Lenape to the "savage" influence of Clithero or to the Lenne Lenape themselves, leaving us to assume that Edgar's violence is merely the result of an unregulated response to a bad "reading" and a naive susceptibility to bad influences. Yet far from meeting Clithero, or the Lenne Lenape, as a blank slate, Edgar, by virtue of his precarious social position in settler society, is fully enwrapped in crisis when he meets Clithero, and his reaction to crisis bears the same marks of contradiction as Clithero's. Edgar is not a receptor of foreign influences. Rather he is a newly and precariously empowered subject responding to "new springs of action and new motives"; that is, he is responding to a crisis of social mobility made from social conditions unique to settler colonialism. ${ }^{36}$

On a physiological level, Edgar is already experiencing the semi-sleepwalking reveries that divorce the internal material of his imagination from the influence of external material in the novel's opening scene when he is walking back home through the forest at night after visiting his fiancée, Mary Waldegrave. The night diminishes the influence of external sensations, unmingling Edgar's internal mental mechanics from the influence of the outside world, allowing the imagination to conjure memories of his recent crisis, the unsolved mystery of his friend Waldegrave's death. The darker and more occluded the scenery, the more his thoughts turn inward and revive memories of his murdered friend and the desire for revenge. He says, "As the darkness increased, my sensations sunk into melancholy," and his "thoughts reverted into some degree of bitterness." 37 It is "the time of night, the glimmering of the stars, the obscurity in which external objects were wrapped, and which consequently did not draw my attention from the images of fancy ... [that] account for the revival of these sentiments and resolution." 38

Edgar's internal obsession, detached as it is from external sensations, even untethers his body from the influence of external nature. It is common to assume that Edgar's mind is influenced by the savage nature of the wilderness and the distance from civilized society, but as these early scenes show, this is

35 See Jared Gardner, "Alien Nation: Edgar Huntly's Savage Awakening," American Literature, 66, 3 (1996), 429-6r. Even though Gardner's essay released Brown studies from the grip of psychoanalysis by turning to national interests, he tacitly takes for granted Fiedler's notion that American history begins with the formation of the nation and doesn't allow for the influence of the domestic social history that precedes Edgar's story. $\quad{ }^{36}$ Brown, Edgar Huntly, 3. $\quad 3_{7}$ Ibid. 6, 7. ${ }^{38}$ Ibid. 7. 
not the case. The churning of internal materials excites his mind to such a degree that he veers off the beaten path and charts a "trackless and intricate" course to the Elm to once again reignite his obsession with finding Waldegrave's murderer. As the internal obsession heats up, his internal processes become more enclosed, and his natural surroundings become little more than barely observed obstacles. Edgar says he "climbed the steeps, crept through the brambles, leapt the rivulets and fences with undeviating aim." ${ }_{39}$ No obstacle slows the momentum of this excited state of reverie. In this way, his steps reflect his zealously animated state of mind, not the wildness of nature. We see this same obsessive walking later when Edgar zealously pursues a sleepwalking Clithero for the second time, again in the dark:

All dangers were overlooked, and all difficulties defied. I plunged into obscurities, and clambered over obstacles, from which, in a different state of mind, and with a different object of pursuit, I should have recoiled with invincible timidity. When the scene had passed, I could not review the perils I had undergone without shuddering. ${ }^{40}$

In this obsessive state of mind, he does not adapt his steps to the natural curvatures and paths of nature; rather his state of mind is dissociated from nature's concrete shapes. When Edgar's body is mobilized by an excited mind, his sense of self-preservation, that rational faculty most closely associated with the integration of the body to nature, is sidelined as his body, charged with extra energy from his obsession, moves him through the wilderness. Edgar embodies a form of mind that is separate and removed from nature, mobilized by internal obsession rather than external wilderness.

Again, we are confronted with the form of the sleepwalker in the semi-sleepwalking state, a form that is not bound by the affective content. Thus we see no abatement in the level of intensity when Edgar's pursuit of revenge shifts to a pursuit of compassion. When he first encounters Clithero near the Elm, he presumes that Clithero is the elusive culprit and pursues him as a suspect, a potential object of revenge. And yet, before Clithero ever utters a word to Edgar, he simultaneously becomes an object of sympathy. Edgar says, "I was suspended in astonishment. Every sentiment, at length, yielded to my sympathy ... Instead of one whom it was duty to persecute, I beheld in this man, nothing but an object of compassion." 41 On the following night, Edgar pursues Clithero as if he is still a suspect, but his conception of Clithero and of the concept of revenge shifts once he hears Clithero's story. When he considers that his "suspicions have appeared to have been misplaced," he wonders whether "the death of my friend [Waldegrave] was, in 
like manner, an act of momentary insanity and originated in a like spirit of mistaken benevolence." 42 This moment of reflection could act as a calming agent, allowing sympathy to quell the affective intensity of vengeance. However, Edgar pursues Clithero through the wilderness as zealously when he is an object of vengeance as when he is an object of compassion. The content of Edgar's affective intensity shifts, but the form of his zeal does not.

Clithero's story does not have an impact on the excited state of Edgar's mind, only on the affective content. It activates an already existing ideology of sympathy to which Edgar is inured as a member of republican settler society. As a social code, sympathy facilitates the internal functioning of commerce and binds merchant capitalists together in a culture of sympathy. 43 However, on the edges of that commercial society, among the dispersed frontier population, sympathy functions in tandem with border violence. Before the events of the novel, Edgar has already experienced a crisis that emerged from these vulnerabilities when his parents were killed in a violent border dispute, and the only means at his disposal to advance socially is his engagement to Mary Waldegrave, who has inherited a large sum of money after her brother's death. But when a merchant named Weymouth shows up claiming that he had entrusted that money with Waldegrave, Edgar mentally processes the event through the discourse of sympathy. This discourse subsequently facilitates the violent encounter with the Lenne Lenape. The discourse of sympathy, then, emerges as a pretext in disputes over property both within and outside colonial society.

Edgar's encounter with Weymouth exposes his vulnerability as a backsettler. Like the newly empowered meritocracy in Europe, the back-settler in postrevolutionary America occupied a novel social position that enabled social mobility and empowered a class of popular subjects by making frontier land available for freehold. As Ed White points out, the dispersed and isolated geographical position of the yeoman settler provided a foundation for the distinctive cultural qualities, their independence and liberation from institutions, but also made them vulnerable to internal and external crises. ${ }^{44}$ We can look to Hector St. John Crèvecoeur's Letters from an American Farmer (1782) for what White calls a "vernacular sociology" of the internal contradictions that

42 Ibid. 63.

43 For an unsurpassed account of the way in which sympathy facilitates political economy in the eighteenth century see Stephen Shapiro, The Culture and Commerce of the Early American Novel: Reading the Atlantic World-System (University Park: Pennsylvania State University Press, 2008).

44 In White's terms, these dispersed communities faced the threat of fused groups in the form of metropolitan colonial authority and organized bands of Native Americans. See White, The Backcountry and the City, chapter 2, "Seriality." 
condition the precarity of the back-settler class and set them in conflict with Indian populations. ${ }^{45}$ The back-settler's geographical location and mode of reproduction make them a bad fit for republican political society and prone to violence. Living far from "long-established communities" and lacking the influence of civilized customs or legal infrastructure, they are left without "the same remedies to these evils as in a long-established community." ${ }_{6} 6$ Split between the not-yet productive employment of clearing land and the hand-to-mouth method of hunting, their habits and behavior are not much better "than carnivorous animals of a superior rank, living on the flesh of wild animals when they can catch them and when they are not able, they subsist on grain." 47 Farmer James describes these settlers as "our bad people ... those who are half cultivators and half hunters; and the worst of them are those who have degenerated altogether into the hunting state." 48 This leaves them not only "in a perfect state of war" amongst themselves but also in a state of war "against every wild inhabitant of these venerable woods, of which they are come to dispossess them." 49

If the geographical distance from society accounts for such brutish behavior, it is the precarity of settler society at its metropolitan core that drives people to the frontier in the first place. According to Crèvecoeur, this low and wild class of frontier settlers "were driven there by misfortunes, necessity of beginnings, desire of acquiring large tracts of land, idleness, frequent want of economy, ancient debts." 50 In other words, these settlers mobilize into the wilderness not by some dream of pursuing wealth and liberty on the frontier but by the nightmare of personal financial crisis. Though eighteenth-century commercial society may facilitate a culture of sympathy among merchants and financiers, the internal contradictions of that society render common people penniless and mobile, forcing them to rough life on the frontier. The mobility that characterizes this popular class of back-settlers, then, is defined not only by the empowering ability to settle new lands but also by the destabilizing position of geographical and financial precarity.

This synchronous account of the habits and behaviors of the back-settler also has a diachronical dimension to it. The "improved" society of the freeholder depends on back-settler labor to pave the way for the more "civilized"

${ }^{45}$ Ibid., 50.

${ }^{46}$ J. Hector St. John de Crèvecoeur, "What Is an American?" in Crèvecoeur, Letters from an American Farmer and Other Essays, ed. Dennis Moore (Cambridge, MA: Belknap Press, 2013), 28-65, 33.

47 Ibid. For an account of the uneasy distinction between animals and humans that Enlightenment colonial society rests on see Janie Hinds, "Deb's Dogs: Animals, Indians, and Postcolonial Desire in Charles Brockden Brown's Edgar Huntly," Early American Literature, 39, 2 (2004), 323-54. ${ }^{48}$ Crèvecoeur, $38 .{ }^{49}$ Ibid. $33 . \quad$ so Ibid. 33. 
elements of the settler colonial regime and the "more industrious people, who will finish their improvements, convert the log house into a convenient habitation and, rejoicing that the first heavy labours are finished, will change in a few years that hitherto barbarous country into a fine, fertile, well-regulated district." ${ }_{5}$ The back-settler is thus a "forlorn hope," a figure that offends the sensibility of the civilized but on whose hard labor the cultivation of settler civilization depends. The class of aristocratic agrarian republicans like Crèvecoeur considered the back-settler repulsive, but they depended on the crises and precarity that repulsed them from "civilized" society to the frontier to create the conditions for expansion. While Crèvecoeur considers the backsettler an essential, if unfortunate, element of progress, Brown sees the reliance on a class of popular subjects, mobilized by financial crisis and subject to geographical precarity, as the structural condition of populist reaction.

But if the ambivalence toward the back-settler expressed by the elite agrarian republicans leaned toward revulsion, the popular movements that arose during the post-Independence conflicts of the 1780 s began portraying the back-settler as a victim of corrupt schemes, greedy speculators, and the prioritization of national credit and speculative enterprises. ${ }^{52}$ This figure of the indebted, bankrupted rural farmer was the basis of a popular politics of sympathy and became the pretext for democratic movements that advocated relief policies such as lower taxes and paper money emissions that prioritized the interests of the farmer class at the expense of the wealthy landowners and speculators. AntiFederalist politics used a rhetoric of sympathy to arouse popular feelings in order to advocate more democratic legislation that would resolve those policies that bankrupted farmers and sent them further west. As Woody Holton points out, popular "authors and orators also wielded sensibility as a cudgel ... When advocates for stringent fiscal and monetary policies claimed their opponents were actuated by emotion rather than reason, pro-relief writers sometimes replied with vigorous defenses of sensibility." ${ }_{33}$ Rather than the vicious halffarmer, half-hunter who was too far removed from civilized sensibilities, this discourse showed that the farmer class was able to employ the discourse of sympathy politically in service of popular indignation.

If the pretext of sympathy enabled common people to participate in political competition by directing their indignation inwardly, toward the metropole, the resolution of that political competition turned outward onto Indian lands. In other words, popular pressure forced Federalist elites to

51 Ibid. 34 .

52 My account of this political culture comes primarily from Bouten, Taming Democracy; and Woody Holton, Unruly Americans and the Origins of the Constitution (New York: Hill and Wang, 2007).

${ }_{53}$ Holton, I $18-19$. 
respond by reconstituting the political order in favor of a pluralist (if not democratic) federalist constitutional structure and by opening up territories for settlement in the Northwest Ordinance. If the Constitution was a recoil against the democratic movements, the Northwest Ordinance was something of an olive branch. By increasing the availability of land, the Northwest Ordinance provided a revenue source for the central government, appeased speculators, and created a path to social mobility for the farmer-settlers. Popular politics became the impetus for a compromise that resulted in expanding the cycle of rationalizing the expropriation of Indian land. Instead of allowing the democratic energies of popular movements to democratize the republicanism of the post-Independence nation and internally redistribute wealth, the Northwest Ordinance rechanneled those energies west, where back-settlers would make way for what Adam Dahl calls an "empire of the people." 54 In pluralist fashion, compromise brought democratic desires into harmony with the expansionist desires of the metropolitan elite, redirected the desires of the people from democratic reforms to settler reforms, and created a popular pretext for settling those lands, ultimately erasing the Indian claims on frontier land.

Edgar's own commitment to sympathy in the scene with Weymouth recreates this very dynamic. Philip Barnard and Stephen Shapiro argue that, by honoring Weymouth's property claims, Edgar enacts a social code that facilitates commercial society even as he looks into the abyss of his own ruin. ${ }^{55}$ Like Clithero, Edgar's place as a popular subject in postrevolutionary America positions him in a contradiction: merchant society is both sympathetic and ruthless. His social mobility is dependent on the cash generated from merchant ventures but is also subject to the fluctuations and instability of that mode of production. Therefore his response to those beyond the border is sympathetic and ruthless. Honoring the claims of the metropolitan merchant would render Edgar bankrupt, reversing his socially upward trajectory. Sympathy certainly plays an ideological role here, as Paul Downes argues. Edgar's commitment to transparency and sympathy would undermine the impulse to censor Weymouth's claims for the sake of his own stability. ${ }^{56}$

54 Adam Dahl says, "Federalism thus emerged as a way of reconciling imperial frameworks of expansion with democratic-republican ideals of self-rule at the local level. By privileging the equality of settler states in relation to the imperial state, federalism provided a means of reconciling conflicts between the imperial authority of the metropolis and the settler sovereignty of colonies. Rather than an alternative to empire, federalism allowed settlers to combine imperial sovereignty with popular sovereignty in a single framework of territorial expansion." Adam Dahl, Empire of the People: Settler Colonialism and the Foundations of Modern Democratic Thought (Lawrence: University Press of Kansas, 2018), 25.

ss Philip Barnard and Stephen Shapiro, "Introduction," in Brown, Edgar Huntly, xxviii-xxxii.

56 See Downes, "Sleepwalking out of the Revolution." 
But, again, by only seeing Edgar as someone struggling dispassionately between two principled discourses, Downes's discursive centered argument cuts off the possibility that ideologies can mix incoherently with more vicious motives like self-interest or resentment. 57 The codes of sympathy that facilitate the metropolitan section of settler society spell financial ruin for Edgar and propel him, like the proto-populist settlers of the early republic, into Indian land. Sympathy in settler society, then, becomes a pretext for violence on its borders. ${ }^{58}$

Though more drawn out and detailed than the Clithero's encounter with Wiatte, Edgar finds himself in a state of instinctive self-preservation that starts upon his awakening in the cave. Just like Clithero, the pattern of instinct and recoil repeats itself beginning with the famous scene in which Edgar's desperate hunger impels him to kill and eat a panther which he promptly regurgitates. A series of violent encounters with a band of Lenne Lenape ensues in which Edgar acts according to an instinctive and dizzying self-preservation. Upon his second awakening, after fainting in the first melee, Edgar recovers his senses more quickly and integrates his body and senses into the external world around him:

On recovering from this swoon, my sensations were not unlike those which I had experienced on awaking in the pit. For a moment a mistiness involved every object and I was able to distinguish nothing. My sight, by rapid degrees, was restored, my painful dizziness was banished, and I surveyed the scene before me with anxiety and wonder. 59

In proportion as Edgar's sensations are integrated into external reality, he recovers and readjusts himself to the customary codes of his society.

And yet Edgar's reattachment to these customary codes does not mean the end of the violence or any sort of progress. In fact, the social codes that he reintegrates into his consciousness become the pretext for violence. In the botched

57 In arguing that sleepwalking represents the "debilitating consequences of thoughtless Enlightenment faith in Reason," Janie Hinds also assumes that Edgar attaches himself to a coherent ideology. However, like Downes, she argues that this commitment is unsustainable because of its discursive contradictions rather than the material contradictions that underlie Edgar's precarious social position. Hinds, "Deb's Dogs," 345.

${ }^{8}$ We must note that Edgar's behavior toward Weymouth is difficult to understand if we think that Edgar only becomes a sleepwalker after his encounter with Weymouth. Butas we've seen, Edgar is already charged with zealous compassion in his pursuit of Clithero. If he too eagerly submits to Weymouth's claim, it is because of his obsessive internal state rather than his mere naivety. Weymouth's news puts Edgar face to face with crisis, inducing an internal panic and sense of displacement, which results in sleepwalking. Sleepwalking is a physical response to a "feeling of structure," a sense of his own social precarity. In the face of crisis Edgar feels the "structural need to move." And as Clithero and Weymouth have become the object of his zealous sympathy, so too do the Lenne Lenape he encounters.

59 Brown, Edgar Huntly, 13 I. 
mercy killing scene that follows, Edgar's compassion is the very cause of gratuitous violence. The scene that Brown creates here is a twisted rendering of the famous scene in Adam Smith's Theory of Moral Sentiments in which the latter argues that the sight of a person suffering in pain elicits sympathy in the viewer. Edgar shoots but does not kill the Lenne Lenape warrior, and at first recoils from the warrior's "doleful shrieks," but when he considers the warrior's sufferings, he decides that he must relieve his suffering, but not by treating him or saving his life (as he will later convince Sarsefield to do with Clithero), but rather by inflicting more violence. Edgar comes to the oxymoronic conclusion that "to kill him outright was the dictate of compassion and duty," a "loathsome obligation" both "worthy of abhorrence" and "prescribed by pity." ${ }^{60}$ And yet, again, this sympathy leads to more suffering and more gratuitously gruesome violence, as Edgar fails to kill the warrior on the second shot. He decides he must stab him in the heart with the bayonet of his musket. In this scene, sympathy, the element and use of the human imagination to create social bonds, works to create violence and death.

This "compassionate murder" is the key symbol of the novel because it compresses the internal and external contradictions of settler society in one act and thereby demonstrates how the populist pretext works. As Stephen Shapiro notes, the act of sympathy is "not meant to alleviate the condition of the abject, but to give evidence of one's sense of appropriate behavior in ways that ensure the viewer's inclusion with the benefits and privileges of collective approbation." ${ }^{61}$ To the extent that Edgar imagines his act as one of mercy and compassion, he is performing an act that accords with the social codes that regulate and facilitate settler society internally. But the violent dimension of the same act expresses the settler society's dependence for its internal dynamics - including its culture of sympathy-on violence against Indians. Edgar's mercy killing represents the fact that in order to maintain the values that facilitate settler society internally, the energies and affects of those internally dispossessed must be rechanneled away from the core and toward the Indian. By both displacing the back-settler through crisis and yet opening the door to inclusion via expropriation of Indian land, settler society creates the condition for the populist violence that erupts on the border.

Edgar's bloody encounter with the Lenne Lenape, just like Clithero's violent encounter with Wiatte, signifies a self-defensive attack against the return of the dispossessed. And, as with Clithero, crisis has jeopardized Edgar's social position, destabilized his identity, and made him prone to

60 Ibid., I 34 .

${ }^{61}$ Shapiro, The Culture and Commerce of the Early American Novel, 64. 
adopting the identity of the very people he attacks. This destabilization of identity is a common theme in crisis literature of early America. We see it in Crèvecoeur's final letter, in which the revolutionary crisis negates the yeoman identity the early letters celebrate and prompts Famer James to consider life with the Indians. As Ed White puts it, "As yeoman seriality disintegrates in war, captivity provides the cohesion necessary to recombine."62

But Edgar's identification with the Lenne Lenape is far from cohesive. In the novel's most iconic moment, Edgar tosses aside his musket and takes up the tomahawk, appropriating an element of Indian identity. Richard Slotkin identifies this appropriation as a new form of masculine identity that serves as something of a cultural entitlement to Indian land. But this highly persuasive analysis of settler culture doesn't account for the role sympathy plays in that identification process. As Adam Smith notes, when we witness suffering, "we conceive ourselves enduring all the same torments, we enter as it were into his body, and become in some measure the same person with him, and thence form some idea of his sensation." ${ }^{63}$ Like the Lenne Lenape, Edgar perceives himself as dispossessed. In his ruin, he is by default expelled from the society that promised him upward mobility. Edgar perceives a shared experience with the Lenne Lenape of being ousted from settler society. Just as Clithero's mind is dominated by the mystical ideology of the displaced aristocratic mode after he feels his own removal from society, Edgar takes up the identity of the displaced Lenne Lenape. And just as Clithero used that ideology to dress up his act of resentment as devotion, Edgar's sympathy becomes the pretext for violence against settler society itself.

Throughout the novel, Edgar's sympathy functions as a weapon. In his early pursuit of Clithero, his sympathetic attachment is tinged with suspicion and a desire for revenge. And even though Edgar's devotion to radical sympathy persuades Sarsefield to save Clithero's life, his intrusive sympathy eventually ends up reconjuring the demon that Clithero has been trying to subdue when he tells him that Mrs. Lorimer and Sarsefield have returned. Edgar's sympathy effectively serves as an attack on Sarsefield and Lorimer. Again and again Edgar, like Clithero, makes sympathy the pretext for violence because, like Clithero, Edgar finds himself in a state of crisis that exposes a deep ambivalence toward the society that has rendered him immobile. Edgar's zealous attachment to sympathy automates his behavior but detaches it from any consideration of its effects on the outside world. This disjunction ends up enacting a hidden resentment towards the people who remain secure under the prevailing

${ }^{62}$ White, The Backcountry and the City, 53.

${ }^{63}$ Adam Smith, The Theory of Moral Sentiments, ed. Knud Hakkonssen (Cambridge: Cambridge University Press, 2002), I 2. 
modes of social reproduction while he stares into the abyss of ruin. Edgar perceives himself as a victim of the internal settlement that empowers him. That is, in order to become an empowered citizen, he, like all settlers, must submit to the precarious order of financial capital and its consequences.

Those late eighteenth-century markers of social mobility - merit-based bureaucratic positions and freehold landownership - which were meant to symbolize more democratic and prosperous transatlantic societies, are the sources of inscrutable reaction in Brown's work. What makes Brown's work so intriguing, however, is that it not only exposes the precarity of these positions but also demonstrates how the contradictions of these novel social relationships directly condition and shape the contradictions of the characters' novel reactions. It dramatizes the way social precarity creates an internal charge in the popular subject that is set off in moments of crisis. The sleepwalker, both asleep and awake, turning their internal material out into the external work, provides Brown with a figure uniquely capable of embodying the paradoxes of modern reaction.

Is it not also the case that our contemporary symbols of social mobilitymilitary enlistment, homeownership, middle-class debt-have been at the center of the most prominent twenty-first-century crises, producing similarly somnambulistic responses in which a distorted logic is amplified and turned out violently against the external world? Twenty-first-century colonial warfare still operates under the popular pretext of sympathy for the rights and freedom of those in the Middle East, even as it lays waste to those countries, and we might see the shadow of Edgar in the many young people who come from communities ravaged by neoliberal globalization for whom colonial wars have been one of a diminishing number of pathways to social mobility. And, though many argue that the contemporary populist moment is something like a structure of feeling targeting a faltering neoliberalism, these movements often look more like an expression of a feeling of neoliberal structure. As Marco Revelli points out, neo-populist movements, with their demands for individual personal responsibility and belt-tightening austerity measures, actually carry with them characteristics of neoliberalism. ${ }^{64}$ The American Tea Party movement, for instance, was the first populist movement to mobilize wrath against bank bailouts, but it ended up directing its anti-elite energy against the victims of the housing crisis, against expansion of health care coverage, and against higher taxes. Like Clithero, they found themselves zealously

\footnotetext{
${ }^{64}$ Marco Revelli, The New Populism: Democracy Stares into the Abyss, trans. Davide Broder
} (New York: Verso, 2019), 32-37. 
mobilizing under the ideological pretexts that support the very people who put social mobility in danger in the first place.

Was the Capitol riot on 6 January 202 I not the ultimate example of a mob of sleepwalkers? Zealously animated by fantasies of a stolen election, the rioters, like Clithero and Edgar, showed no regard for physical barriers as they leapt fences, scaled walls, and smashed windows to enter the Capitol. Yet once inside, spectral aggression gave way to the mundane as most found themselves wandering the halls of Congress taking selfies, rifling through documents, marveling at the paintings and monuments, aimlessly performing everyday habits in the middle of an insurrection. Politically, they were paradoxically trying to save democracy by disrupting its most basic procedure. And yet, as became clear soon after, many of these people were beset by foreclosure, bankruptcy, and debt, raising the question whether their zeal lay not in political representation or even in the pretext of a stolen election but in a mode of social crisis. ${ }^{65}$

The patterns in Edgar Huntly teach us that the worlds that grew out of the promises of modern revolution were and continue to be contradictory and unstable. Brown does not base his skepticism of revolutionary society on old antidemocratic prejudices but on a newer sense of the risks and implications of new social arrangements, especially that of the newly empowered but precariously positioned people who have the power to react.

\section{AUTHOR BIOGRAPHY}

Wayne M. Reed received a PhD in Literature from Florida State University, where he currently holds a Visiting Teaching Fellowship. He specializes in American literature from the American Revolution to the Civil War and researches the literary portrayal of the relationship between social mobility and democracy. He expresses deepest gratitude to Sheila, Kieran, and Reva; to Barry Faulk for his thoughtful and encouraging reading of the essay; and to the journal's external readers, whose insightful comments were immensely helpful in shaping it.

6s Todd C. Frankel, "A Majority of the People Arrested for Capitol Riot Had a History of Financial Trouble," Washington Post, Io Feb. 2021, at www.washingtonpost.com/business/ 202 I/02/10/capitol-insurrectionists-jenna-ryan-financial-problems. 